medRxiv preprint doi: https://doi.org/10.1101/2022.02.01.22270281; this version posted February 2, 2022. The copyright holder for this preprint (which was not certified by peer review) is the author/funder, who has granted medRxiv a license to display the preprint in perpetuity.

All rights reserved. No reuse allowed without permission.

\title{
Towards increasing equity in healthcare among transgender women: a cross-sectional analysis of self-reported needs and health service utilization in Lima, Peru
}

Elizabeth A. Carosella ${ }^{1}$, Leyla Huerta ${ }^{2}$, Jerome T. Galea ${ }^{3,4}$, Leonid Lecca ${ }^{3,5}$, Karen Ramos ${ }^{5}$, Giulianna Hernandez ${ }^{5}$, Molly F. Franke ${ }^{3 *}$, Jesus Peinado ${ }^{* \diamond}$

${ }^{1}$ Harvard T.H. Chan School of Public Health

${ }^{2}$ Féminas de Lima

${ }^{3}$ Department of Global Health and Social Medicine, Harvard Medical School

${ }^{4}$ University of South Florida, School of Social Work

${ }^{5}$ Partners In Health/Socios En Salud

*Contributed equally

$\diamond$ Corresponding author

\section{Abstract}

Globally, transgender women experience wide-ranging barriers to health and care, with disproportionately high risks of infectious and chronic diseases, mental illness, violence, and substance abuse. Despite these vulnerabilities, research on transgender populations in low- and middle-income countries is extremely limited. Furthermore, existing studies have primarily focused on HIV/AIDS, with less emphasis on transgender women's broader health needs. This cross-sectional study conducted in Lima, Peru aimed to analyze patterns of morbidity and health service uptake to identify subgroups that be especially in need of health interventions to improve access. We identified suboptimal levels of health coverage and access to care, with less education and older age as important risk factors for self-reported illness and HIV and tuberculosis (TB) testing, and differential HIV testing and pre-exposure prophylaxis (PrEP) usage among gender identity subgroups within Peru's broader community of transgender women. Both awareness of and interest in PrEP were suboptimal, and usage was low among those who were interested in taking PrEP. Future public health efforts should be tailored to the diverse needs of transgender women, bridge the gap between PrEP interest and use, and increase insurance coverage and access to trans-friendly services to promote improved health outcomes and equity.

\section{Introduction}

Transgender women — individuals born as or assigned male sex at birth who identify as femaleexperience severe and wide-ranging structural, cultural, and interpersonal barriers to health. Gender-based 
medRxiv preprint doi: https://doi.org/10.1101/2022.02.01.22270281; this version posted February 2, 2022. The copyright holder for this preprint (which was not certified by peer review) is the author/funder, who has granted medRxiv a license to display the preprint in perpetuity.

All rights reserved. No reuse allowed without permission.

stigma leads to marginalization and vulnerability, which undermine transgender women's educational attainment, safe employment, and access to and utilization of healthcare. ${ }^{1}$ As a result, transgender women suffer disproportionately high rates of sexually transmitted infections (STIs), substance abuse, physical violence and injury, mental illness, and chronic diseases. ${ }^{2} 34$

Latin America is one of the least hospitable places for transgender women in the world, with nearly $80 \%$ of reported murders of transgender people globally occurring in the region. ${ }^{5}$ Transphobia accompanies cultural conservativism and pervasive machismo, ${ }^{6,7}$ a concept of masculinity that is characterized by traditional beliefs about gender roles and men's superior status in society and associated with controlling, aggressive attitudes and behaviors. Despite recent regulatory improvements in some countries, most Latin American countries deny transgender women legal recognition of their gender identity, access to gender affirming care, and a host of other benefits and protections. ${ }^{8}$ Transgender women experience widespread discrimination and abuse, including at health facilities, where providers may refuse treatment or give inadequate care. ${ }^{9}$ Transgender women are often forced to leave home after experiencing physical, sexual, and/or verbal violence and family rejection, ${ }^{10}{ }^{11}$ with many migrating to cities where they have few resources and support networks. ${ }^{12}$ High prevalence of sex work, often one of the only livelihood options available, ${ }^{13} 14$ is linked with risky behaviors ${ }^{15}$ and increases risks for STIs and other infectious diseases. ${ }^{16} 13$

While the evidence base around sexual health and HIV/AIDS among transgender women has grown, their broader health needs and healthcare utilization remain understudied. ${ }^{4}{ }^{17}$ Data on transgender populations are scarce, in part, because until recently it was common practice to combine this population with MSM. Indeed, less than $0.01 \%$ of published articles in PubMed focus on transgender populations, with the majority from the United States and other high-income countries. ${ }^{18}$ A limitation to existing epidemiologic research of transgender women is that it largely assesses them as a single, homogenous group. However, there are diverse gender identities within the broader transgender community that impact social perceptions, lived experiences, and behavior trends. ${ }^{19}$ In Peru, commonly used terminology 
medRxiv preprint doi: https://doi.org/10.1101/2022.02.01.22270281; this version posted February 2, 2022. The copyright holder for this preprint (which was not certified by peer review) is the author/funder, who has granted medRxiv a license to display the preprint in perpetuity.

All rights reserved. No reuse allowed without permission.

ascribes different individual characteristics: "travesti," refers to transgender women who "utilize female dress full time," while "transformistas," alternate between masculine and feminine appearance, often presenting as male in public places or places of work. ${ }^{19}$ The umbrella term "trans," on the other hand, is not consistently applied in the literature or in practice. ${ }^{4}$ There is also a lack of quantitative research on sub-groups within Peru's transgender women community to understand which groups may be at higher risk of poor health or barriers to healthcare utilization.

Our research sought to improve understanding and promote visibility of the health inequities facing Peru's transgender women. Specifically, this cross-sectional study aimed to identify risk factors and patterns of morbidity and health service uptake to identify the most vulnerable subgroups within this population, and to inform future public health outreach and interventions.

\section{Methods}

Study setting: The exact size of the transgender women population in Peru is unknown, and there is no national population- level data on transgender health. Research from the United States ${ }^{20}{ }^{21}$ estimates $^{-1}$ transgender identity prevalence at between $0.3 \%$ to $0.5 \%$, which, if applied to Peru would suggest that the transgender population could be close to 165,000 people. HIV prevalence among transgender women is extremely high at $30 \%,{ }^{13}$ in contrast to $12 \%-22 \%$ among men who have sex with men (MSM), ${ }^{22}$ and less than $1 \%$ prevalence in the general population. ${ }^{23}$ Yet, less than a quarter of transgender women know their HIV status. ${ }^{24}$ In 2016, Peru's Ministry of Health (MINSA) issued Ministerial Resolution 980-2016MINSA, ${ }^{25}$ establishing guidelines for healthcare delivery to transgender women, specifically aimed at STI and HIV infection prevention and control. HIV and syphilis testing is currently recommended on a quarterly basis for transgender women. The resolution also outlines hepatitis B vaccination and distribution of condoms and lubricant. These prevention and control strategies are the focus of MINSA health campaigns with transgender women. The resolution also codifies the process for hormone therapy. Health providers are required to have knowledge of hormone therapy, though only surgical doctors with specialized training involving transgender patients may administer it. A psychological evaluation and 
medRxiv preprint doi: https://doi.org/10.1101/2022.02.01.22270281; this version posted February 2, 2022. The copyright holder for this preprint (which was not certified by peer review) is the author/funder, who has granted medRxiv a license to display the preprint in perpetuity.

All rights reserved. No reuse allowed without permission.

informed consent are also required before initiating treatment. In practice, however, few public facilities are equipped to provide these services and most transgender-sensitive and gender affirming healthcare available is accessed through the private sector ${ }^{26}$ or in conjunction with participation in clinical researchmost commonly HIV clinical trials. ${ }^{27}$

Peru's food and drug administration approved pre-exposure prophylaxis (PrEP) in 2017 following its participation in the landmark iPrEx trial. However, there is a continued lack of national policies and guidelines, which contributes to limited uptake. Mostly, PrEP is accessible to transgender women though participation in research, such as the MINSA-sponsored ImPrEP demonstration project, ${ }^{28}$ or buying it over the counter. ${ }^{29}$ The organization PrEP Watch estimates that there are only 2,500 - 3,000 PrEP users in Peru as of October $2021 .^{30}$

Study design and population: We conducted a cross-sectional study of characteristics and health service utilization among Peruvian transgender women in the capital city of Lima, with data collected between September - October 2020. The study population was transgender women recruited from 21 of 43 districts in Lima who are affiliated with the non-government organization (NGO), Féminas de Lima, a grassroots advocacy organization dedicated to improving health and empowering transgender women through information campaigns, community organizing, political advocacy, and social activism. ${ }^{31}$ Féminas is the oldest organization of its kind in Peru and has one of the most extensive networks of transgender women in the country.

Participants and recruitment: The recruitment process occurred in two steps: first, all Féminas members in participating districts were contacted by phone and invited to participate, after which peer enumerators - transgender women affiliated with Féminas - made in-person visits with each respondent to administer the survey. Inclusion criteria were that respondents be at least 18 years of age, identify as transgender women, and reside in a district of metropolitan Lima, with confirmation by a Féminas peer enumerator. Participants were excluded if they lacked capacity to consent or complete the survey, or reported active SARS-CoV-2 symptoms. Each participant who met the criteria gave informed consent. Of 
medRxiv preprint doi: https://doi.org/10.1101/2022.02.01.22270281; this version posted February 2, 2022. The copyright holder for this preprint (which was not certified by peer review) is the author/funder, who has granted medRxiv a license to display the preprint in perpetuity.

All rights reserved. No reuse allowed without permission.

a total of 311 transgender women who were invited to participate, 10 either refused to participate or did not respond to phone calls, leaving a total of 301 people completed the survey. Participants were drawn from Féminas de Lima's extensive network, with near even participation of transgender women who were originally from Lima (46.5\%) as those originally from other regions of the country $(53.5 \%)$.

Data collection: Respondents filled out paper surveys, which took approximately 40 minutes to complete. These were then digitized by study staff and uploaded to a central database. The objective of the survey was to understand the broader health profile, including service utilization, of transgender women in Lima with the ultimate aim of informing future public health outreach and interventions. Survey questions addressed demographics, stigma, discrimination, drug and alcohol consumption, access to health services, TB and HIV testing, PrEP knowledge and usage, and mental health.

Ethical considerations: The research protocol and informed consent were approved by the Institutional Review Board of National Health Institute of the Ministry of Health in June 2020 (OEE-00220). Participants were provided condoms, lubricants, personal hygiene, and information on where they could access free HIV tests offered by the Ministry of Health.

Statistical Analysis: Data were analyzed in Stata 17 (StataCorp LP, College Station, TX, USA). Sample characteristics (i.e., age group, education, department of origin, employment, and gender identity) were described by frequencies and percentages. Age was examined as a categorical variable (i.e., younger than 27 years, $27-36$, and 36 and older), with the upper and lower thresholds corresponding to the highest and lowest quartiles of the distribution. For analyses of gender identity, the self-reported categories of "trans" and "transgender" were pooled into the "trans" category, as Féminas leadership confirmed that these terms are understood synonymously. Next, we evaluated whether these characteristics predicted binary outcomes of insurance coverage, self-reported illness, regular clinic attendance, TB and HIV testing, and PrEP usage. Bivariate Poisson regression models with robust error variance were fitted to calculate unadjusted prevalence ratios (PRs) and $95 \%$ confidence intervals. We 
medRxiv preprint doi: https://doi.org/10.1101/2022.02.01.22270281; this version posted February 2, 2022. The copyright holder for this preprint (which was not certified by peer review) is the author/funder, who has granted medRxiv a license to display the preprint in perpetuity.

All rights reserved. No reuse allowed without permission.

then fitted multivariable models to report prevalence ratios (aPRs) and 95\% confidence intervals, adjusted for the other predictors of interest, some of which may confound one another.

\section{Results}

\section{Descriptive Statistics}

\section{Socio-demographics}

Socio-demographic characteristics among

301 transgender women participants are shown in

Table 1. Mean age was 32.4 years (range 18-64), and $99 \%$ of the sample were aged 57 or younger;

$57.1 \%$ had completed secondary school and $36.5 \%$ had completed higher than secondary education.

The vast majority were currently working (79.1\%),
Table 1: Characteristics of a Sample of Transgender Women in Lima, Peru ( $\mathbf{N}=\mathbf{3 0 1})$

\begin{tabular}{ll} 
Characteristic & $\begin{array}{l}\text { Mean } \pm \text { SD } \\
\text { n }(\%)\end{array}$ \\
\hline Age & \\
Mean & $32.4 \pm 8.44$ \\
Education & \\
s Primary & $19(6.3)$ \\
Secondary & $172(57.1)$ \\
> Secondary & $110(36.5)$ \\
Origin & \\
\hline Lima & $140(46.5)$ \\
Other regions & $161(53.5)$ \\
Employment & \\
\hline Currently working & $238(79.1)$ \\
Business & $59(19.6)$ \\
Independent (non-sex work) & $50(16.6)$ \\
Sex Work & $145(48.2)$ \\
Gender identity & \\
Woman & $46(15.3)$ \\
Trans & $176(58.5)$ \\
Transsexual & $25(8.3)$ \\
Transformista & $27(9.0)$ \\
Travesti & $21(7.0)$ \\
Other & $6(2.0)$ \\
&
\end{tabular}

and sex work was the most common livelihood reported (48.2\%). More than half were originally from outside of Lima (53.5\%). Many reported living in shared spaces or communal homes: $38.2 \%$ reported renting a single room and another $10.6 \%$ lived in hostels. Trans or transgender $(58.5 \%)$ was the most common gender identity, followed by women (15.3\%), transformistas $(9.0 \%)$, transsexuals $(8.3 \%)$, and travestis $(7.0 \%)$.

\section{Healthcare utilization}

Insurance: As described in Table 2, more than a third (35.2\%) of the respondents were uninsured. Of those with insurance, the subsidized public health insurance Seguro Integral de Salud (SIS) (translated as "Comprehensive Health Insurance") was the most common (53.8\%), followed by the contributory public social health insurance (EsSalud) (7\%), private insurance (3.7\%), and supplementary private insurance (EPS) $(0.3 \%)$. 
medRxiv preprint doi: https://doi.org/10.1101/2022.02.01.22270281; this version posted February 2, 2022. The copyright holder for this preprint (which was not certified by peer review) is the author/funder, who has granted medRxiv a license to display the preprint in perpetuity.

All rights reserved. No reuse allowed without permission.

Clinic Attendance: The proportion of

transgender women who regularly attend a hea 1th

clinic was relatively high $(80.1 \%)$, with most

accessing the public system (83.4\%).

$H I V$ and $T B$ : The vast majority of

participants reported prior testing for HIV (96.3\%),

though testing frequency within 12-months was

lower (57.5\%). In contrast, a considerable

percentage of respondents (36.5\%) had never been

evaluated for TB. Of the total sample, $60.1 \%$ were

aware of PrEP. Among transgender women who had

knowledge of PrEP, over half (55.8\%) were

interested initiating it (33.6\% of the total sample),

while $21.0 \%$ of those who had heard of PrEP $(12.6 \%$

of the total sample) were already PrEP users.
Table 2: Health and Service Utilization among a Sample of Transgender Women in Lima, Peru (N=301)

$\begin{array}{ll}\text { Service } & \mathbf{n}(\mathbf{\%}) \\ \text { Insurance } & \\ \text { No Insurance } & 106(35.2) \\ \text { SIS } & 162(53.8) \\ \text { ESSALUD } & 21(7.0) \\ \text { Private Insurance } & 11(3.7) \\ \text { EPS } & 1(0.3) \\ \text { Clinic Attendance } & \\ \text { Attend health clinic } & 241(80.1) \\ \quad \text { Public } & 201(83.4) \\ \quad \text { Private } & 40(16.6) \\ \text { Illness } & \\ \text { Report suffering from illness } & 62(20.6) \\ \text { No illness reported } & 239(79.4) \\ \text { HIV Testing Frequency } & 139(46.2) \\ \text { In the last 6 months } & 34(11.3) \\ \text { 6-12 months ago } & 117(38.9) \\ \text { Over a year ago } & 11(3.7) \\ \text { Never } & \\ \text { TB Testing Frequency } & 46(15.3) \\ \text { In the last 6 months } & 19(6.3) \\ \text { 6-12 months ago } & 126(41.9) \\ \text { Over a year ago } & 110(36.5) \\ \text { Never } & \\ \text { PrEP } & 181(60.1) \\ \text { Heard of PrEP } & 101(55.8) \\ \quad \text { Interested in PrEP (N=181) } & 38(21.0) \\ \text { Taking PrEP (N=181) } & 275(91.4) \\ \text { Gender Enhancement/ Affirmation } & 225(81.8) \\ \text { Accessed gender enhancement } & 1(0.4) \\ \quad \text { Hormone or silicone injection } & 40(14.6) \\ \quad \text { Surgical procedure without SRS } & 9(3.3) \\ \quad \text { Other } & \\ & \\ \quad & \end{array}$

Gender Enhancement/Affirmation: Respondents commonly reported access to some form of gender enhancement procedures (91.4\%); among these, the majority reported non-surgical procedures.

\section{Factors associated with health care usage}

Age: Compared with those younger than 27, older transgender women had lower prevalence of being uninsured (aPR for 27 - 36 years: 0.62 (95\% confidence interval [CI]: 0.43, 0.90); aPR for those $\geq$ 36 years: 0.67 (95\% CI: 0.43, 1.04), Table 3). Older transgender women, particularly those 36 years of age and older were also less likely to have ever had an HIV test (aPR for those $\geq 36$ years $=0.68,95 \%$ CI: $0.45,1.01$ ) or TB test (aPR for $27-36$ years: $=0.57,95 \%$ CI: $0.31,1.05$; aPR for $\geq 36$ years $=0.27,95 \%$ CI: $0.10,0.72)$. Older transgender women were relatively more likely to report illness and clinic 
medRxiv preprint doi: https://doi.org/10.1101/2022.02.01.22270281; this version posted February 2, 2022. The copyright holder for this preprint (which was not certified by peer review) is the author/funder, who has granted medRxiv a license to display the preprint in perpetuity.

All rights reserved. No reuse allowed without permission.

attendance, though confidence intervals for these estimands were wider and included one (Table 3). Older age was also significantly associated with reduced prevalence of sex work (aPR for $27-36$ years: 0.69 (95\% CI: $0.55,0.87)$; aPR for those $\geq 36$ years: 0.44 (95\% CI: $0.31,0.64)$ ).

Education: Compared with respondents who had higher than secondary education, transgender women with primary education or less had a higher prevalence of being uninsured $(\mathrm{aPR}=1.77,95 \% \mathrm{CI}$ : $1.04,3.03)$ and reporting illness ( $\mathrm{aPR}=2.61,95 \% \mathrm{CI}: 1.07,6.40)$. They also were less likely to report $\mathrm{TB}$ testing (aPR $=0.29,95 \% \mathrm{CI}: 0.05,1.89), \mathrm{HIV}$ testing (aPR $=0.71,95 \% \mathrm{CI}: 0.40,1.24)$, and PrEP utilization $(\mathrm{aPR}=0.44,95 \% \mathrm{CI}: 0.08,2.54)$, though confidence intervals were wide around some estimates.

Origin: We did not find strong evidence that origin outside of Lima predicted the outcomes under study.

Employment: Employed transgender women had a significantly lower relative prevalence of selfreported illness $(\mathrm{aPR}=0.48,95 \% \mathrm{CI}: 0.27,0.85)$ and were less likely to report clinic attendance $(\mathrm{aPR}=0.88,95 \% \mathrm{CI}: 076,1.02)$. The relationship between employment and illness or clinic attendance did not appear to depend on whether that employment was sex work $(\mathrm{p}$-value for interaction $=0.31)$. Employment did not appear to impact TB testing (aPR=1.01, 95\% CI: $0.47,2.18)$ or HIV testing $(\mathrm{aPR}=0.95,95 \%$ CI: 0.66, 1.37).

Gender Identity: Transgender women who identified as women were more likely to test for HIV $(\mathrm{aPR}=1.49,95 \% \mathrm{CI}: 1.16,1.91)$ and $\mathrm{TB}(\mathrm{aPR}=1.69,95 \% \mathrm{CI}: 0.89,3.22)$, and to use PrEP $(\mathrm{aPR}=2.36$, 95\% CI: $1.15,4.80)$ compared to those who identified as trans or transgender. Self-identified women also had a higher relative prevalence of surgical procedures: PR: $1.73(0.92,3.24)$. Those who indicated their gender identity as "other" were significantly more likely to use PrEP (aPR=5.64, 95\% CI: 2.75, 11.58).

\section{Discussion}


medRxiv preprint doi: https://doi.org/10.1101/2022.02.01.22270281; this version posted February 2, 2022. The copyright holder for this preprint (which was not certified by peer review) is the author/funder, who has granted medRxiv a license to display the preprint in perpetuity.

All rights reserved. No reuse allowed without permission.

This study identified a diverse population with varying health needs and service utilization patterns. Overall, we found suboptimal levels of health coverage and care among transgender women, while education and age emerged as important risk factors for many outcomes. In the first study to quantitatively examine health utilization by gender identity subgroups in Peru, we also found that transgender women who identify as women had higher HIV testing and PrEP uptake compared to those who identify as trans or transgender.

Nearly one in five respondents did not receive healthcare through a health clinic. This may be due to a combination of factors that contribute to poor linkages to and retention in healthcare. ${ }^{32}$ Over one third of our sample did not have health insurance of any kind, with younger and less educated transgender women least likely to be insured. In Peru, national ID cards typically do not reflect transgender women's true gender identity, ${ }^{33}$ which can obstruct administrative processes or elicit harassment from authorities. Many transgender women either lack ID cards entirely or do not use them for fear of being subjected to ridicule or abuse, including in health centers. ${ }^{33}$ Because national ID cards are required for Peruvians to enroll in coverage through the SIS, despite regulatory changes in recent years to loosen restrictions for changing gender on national IDs, this remains a barrier to healthcare access.

The lack of differentiated services or trans-friendly spaces within Peru's health system is likely another important barrier. ${ }^{26}$ Gender affirming healthcare is rarely provided in public facilities and we found high prevalence of non-surgical gender enhancement practices- mainly, hormone injections and silicone implants, which are often obtained outside the health system without medical supervision. ${ }^{13} 1912$ Previous studies found that many transgender women self-administer treatments or rely on medicallyunqualified acquaintances. ${ }^{13} 19$ Medical providers and staff may lack training and cultural competency to provide quality health services to transgender women, ${ }^{34}{ }^{26}$ and the expectation of hostile, discriminatory, or substandard treatment may deter even those transgender women who have public health insurance from seeking facility-based care. To date most scholarship has focused on patient perspectives, however, and 
medRxiv preprint doi: https://doi.org/10.1101/2022.02.01.22270281; this version posted February 2, 2022. The copyright holder for this preprint (which was not certified by peer review) is the author/funder, who has granted medRxiv a license to display the preprint in perpetuity.

All rights reserved. No reuse allowed without permission.

there is a need for more research on providers' knowledge, attitudes, and other supply-side barriers to care facing transgender women.

Though HIV testing rates were generally high, we identified disparities by age and education level, with older and less educated transgender women less likely to have been tested. Older transgender women may have had less exposure or access to preventive testing, free anti-retroviral treatment, and informational and anti-stigma campaigns, which have become more common over time. In addition, though nearly half of respondents engage in sex work, putting them at increased risks for HIV, HIVassociated TB, and other STIs, ${ }^{15}$ increasing age was associated with a decline in sex work. Older women may have a reduced HIV risk or perception of risk, leading them to test less frequently.

We also found that transgender women who identify as women were $54 \%$ more likely to have been tested for HIV. A sub analysis found that self-identified women had nearly twice the rate of surgical procedures compared to those who identified as trans or transgender. Together with findings on testing rates, this might reflect that having a physical appearance that aligns with a traditional binary gender reduces some friction in transgender womens' interaction with the health system. It could be that identifying as a woman is a marker of access to care. More qualitative research on how different gender identities impact the testing and broader healthcare utilization could better illuminate this finding. We also note that this research exclusively studied transgender women, and that there is little research available on Peruvian transgender men or non-binary populations.

About two in five transgender women (39.9\%) had never heard of PrEP, and there was a large gap between those who expressed interest in PrEP (55.8\%) and, among those who had heard of PrEP, reported using it (21.0\%). Among the overall sample, prevalence of PrEP usage was just $12.6 \%$. Prior research found that anticipated out-of-pocket costs over time greatly reduced acceptability of PrEP and also documented concerns among transgender women that PrEP would disincentivize condom usage among PrEP users. ${ }^{35}$ Another factor is the mistrust of medical institutions, including widespread doubts about safety and efficacy and suspected ulterior motives of international actors offering free PrEP, 
medRxiv preprint doi: https://doi.org/10.1101/2022.02.01.22270281; this version posted February 2, 2022. The copyright holder for this preprint (which was not certified by peer review) is the author/funder, who has granted medRxiv a license to display the preprint in perpetuity.

All rights reserved. No reuse allowed without permission.

reduced acceptance. ${ }^{27}$ Perez-Brumer et al. found that limited perceived benefits, research clinicians' disregard of PrEP-related side effects, and feelings of exploitation in the face of persistent barriers to PrEP access outside of research environments fueled mistrust. Further qualitative research among those who reported interest but not uptake could help to disentangle supply- versus demand-side factors and inform communication strategies to improve knowledge and increase demand for PrEP. It is also unclear why participants who selected "other" as their gender identity group had significantly greater PrEP usage. This group may include transgender women in transition or who have not embraced a single gender identity label. ${ }^{36}$ Looking forward, long-acting injectable PrEP, cabotegravir (CAB - LA) ${ }^{37,38}$ and was approved by the US FDA in December 2021, ${ }^{39}$ may reduce barriers related to the stigma of daily oral medication, dosing, and adherence.

TB testing was low with over a third of the sample never tested and another 4 in 10 transgender women reporting that they had not been tested for at least a year. TB is an important public health concern in Peru, which has the second highest TB incidence in the western hemisphere and is the only Latin American country on the WHO's top 30 high multi-drug resistant TB (MDR-TB) burden countries. ${ }^{40}$ In addition to the high national burden of TB and its well-established circular relationship with HIV/AIDS, many transgender women in Lima cluster together in communal homes, which can speed TB transmission from infected housemates. Because stigma and discrimination is so extreme, transgender women are not accepted in most neighborhoods: among our sample, nearly half live in shared housing or hostels in the few districts where they can secure housing ${ }^{31,41}$. Thus, transgender women likely are at a disproportionately high risk of TB infection. However, to our knowledge, there is no published data on TB incidence or prevalence among transgender women in Peru. Research in other countries suggests that TB poses a significant risk to transgender women's health: a recent study found pulmonary TB infection among $52.6 \%$ of sampled transgender women in Papua New Guinea. ${ }^{42}$

Whereas public health efforts to expand HIV testing have explicitly targeted transgender women throughout Peru, there is wide variation in TB knowledge and testing levels. Among our sample in Lima, 
medRxiv preprint doi: https://doi.org/10.1101/2022.02.01.22270281; this version posted February 2, 2022. The copyright holder for this preprint (which was not certified by peer review) is the author/funder, who has granted medRxiv a license to display the preprint in perpetuity.

All rights reserved. No reuse allowed without permission.

we saw a major drop in testing among older transgender women - those 36 and over were $70 \%$ less likely to have ever been tested. Although our sample included a broad range of ages (18-64) and was relatively young - the vast majority can be categorized according to current MeSH classifications ${ }^{43}$ as adult (19-44) or middle aged (45-64), Negin et al. identified a growing disease burden among older adults in Latin America. Targeted outreach to these groups is important to connect them to TB testing and treatment. Along with existing HIV programs, there may also be opportunities to build on recent strategies and infrastructure for COVID-19 testing.

\section{Limitations}

This was an exploratory analysis aiming to identify subgroups of transgender women who could be targeted for interventions to improve access to care. As such, we examined a number of correlates and outcomes. We did not adjust for multiple comparisons because sample size was variable and we sought to identify disparities based on patterns of utilization rather than one-off associations. There is potential for selection bias; however, we expect that this is limited given Féminas' extensive network and the high participation rate. The study relied on self-reporting rather than structured diagnostic interviews or verification of medical records, which could result in misclassification of some exposure or outcome variables, thereby introducing bias, the direction of which may be difficult to predict. Finally, meanings associated with gender identity labels are consistently evolving: certain terms, like "transsexual," become less commonly used and others like "trans" begin to subsume previous catch-all terms like "travesti." This may limit interpretation or generalizability of associations with specific gender identity labels presented in this paper.

\section{Conclusion}

Our findings highlight continuing barriers to health coverage and services among Peruvian transgender women. Public health outreach and interventions should aim to expand insurance coverage and extend access to trans-friendly services for transgender women who do not seek care through the 
medRxiv preprint doi: https://doi.org/10.1101/2022.02.01.22270281; this version posted February 2, 2022. The copyright holder for this preprint (which was not certified by peer review) is the author/funder, who has granted medRxiv a license to display the preprint in perpetuity.

All rights reserved. No reuse allowed without permission.

formal health system, particularly younger transgender women. While HIV testing rates are high, PrEP uptake remains suboptimal among this high-risk population, and further efforts are needed to bridge the gap between interest and usage. Finally, TB research and testing must dramatically increase, though there may be synergies with existing HIV and COVID-19 programs that can be leveraged.

\section{Acknowledgements}

We are grateful to the study participants for sharing their experiences. Socios En Salud Peru developed the survey, collected the data and analyzed findings. Féminas co-designed the survey, supplied peer community health workers, and contributed to the analysis.

\section{Author Disclosure Statement}

All authors declare no conflict of interest. 
Table 3: Relative Risks: Healthcare Utilization and Access among a Sample of Transgender Women in Lima, Peru

\begin{tabular}{|c|c|c|c|c|c|c|c|c|c|c|c|c|c|}
\hline \multirow{3}{*}{$\begin{array}{l} \\
\begin{array}{l}\text { Total } \\
\text { N=301 }\end{array} \\
\end{array}$} & & \multicolumn{2}{|l|}{ Uninsured } & \multicolumn{2}{|l|}{ Illness } & \multicolumn{2}{|c|}{ Clinic Attendance } & \multicolumn{2}{|l|}{ TB Testing } & \multicolumn{2}{|l|}{ HIV Testing } & \multicolumn{2}{|l|}{ PrEP } \\
\hline & & \multicolumn{2}{|l|}{ PR $(95 \%$ CI) } & \multicolumn{2}{|l|}{ PR (95\% CI) } & \multicolumn{2}{|c|}{ PR (95\% CI) } & \multicolumn{2}{|l|}{ PR (95\% CI) } & \multicolumn{2}{|l|}{ PR (95\% CI) } & \multicolumn{2}{|c|}{ PR (95\% CI) } \\
\hline & & $\begin{array}{l}\text { Un- } \\
\text { adjusted }\end{array}$ & Adjusted $\diamond$ & $\begin{array}{l}\text { Un- } \\
\text { adjusted }\end{array}$ & Adjusted $\diamond$ & $\begin{array}{l}\text { Un- } \\
\text { adjusted }\end{array}$ & Adjusted $\diamond$ & $\begin{array}{l}\text { Un- } \\
\text { adjusted }\end{array}$ & Adjusted $\diamond$ & $\begin{array}{l}\text { Un- } \\
\text { adjusted }\end{array}$ & Adjusted $\diamond$ & $\begin{array}{l}\text { Un- } \\
\text { adjusted }\end{array}$ & Adjusted $\diamond$ \\
\hline \multicolumn{14}{|l|}{ Age Group } \\
\hline$<27 \mathrm{yrs}$ & $24.3 \%$ & Reference & $\mathrm{N} / \mathrm{A}$ & N/A & N/A & N/A & N/A & N/A & N/A & N/A & N/A & N/A & N/A \\
\hline $27-36$ yrs & $46.8 \%$ & $\begin{array}{c}0.62 \\
(0.43,0.89)^{*}\end{array}$ & $\begin{array}{c}0.62 \\
(0.43,0.90)^{*}\end{array}$ & $\begin{array}{c}1.29 \\
(0.63,2.64)\end{array}$ & $\begin{array}{c}1.13 \\
(0.55,2.32)\end{array}$ & $\begin{array}{c}1.10 \\
(0.93,1.29)\end{array}$ & $\begin{array}{c}1.08 \\
(0.91,1.27)\end{array}$ & $\begin{array}{c}0.69 \\
(0.39,1.24)\end{array}$ & $\begin{array}{c}0.57 \\
(0.31,1.05)\end{array}$ & $\begin{array}{c}1.02 \\
(0.771 .36)\end{array}$ & $\begin{array}{c}0.93 \\
(0.71,1.23)\end{array}$ & $\begin{array}{c}0.58 \\
(0.30,1.13)\end{array}$ & $\begin{array}{c}0.70 \\
(0.35,1.37)\end{array}$ \\
\hline$>36 \mathrm{yrs}$ & $28.9 \%$ & $\begin{array}{c}0.63 \\
(0.42,0.96)^{*}\end{array}$ & $\begin{array}{c}0.67 \\
(0.43,1.04)^{*}\end{array}$ & $\begin{array}{c}2.32 \\
(1.16,4.66)^{*}\end{array}$ & $\begin{array}{c}1.58 \\
(0.78,3.22)\end{array}$ & $\begin{array}{c}1.19 \\
(1.00,1.40)\end{array}$ & $\begin{array}{c}1.15 \\
(0.97,1.36)\end{array}$ & $\begin{array}{c}0.27 \\
(0.11,0.71)^{*}\end{array}$ & $\begin{array}{c}0.27 \\
(0.10,0.72)^{*}\end{array}$ & $\begin{array}{c}0.62 \\
(0.42,0.93)^{*}\end{array}$ & $\begin{array}{c}0.68 \\
(0.45,1.01)^{*}\end{array}$ & $\begin{array}{c}0.79 \\
(0.37,1.66)\end{array}$ & $\begin{array}{c}1.05 \\
(0.47,2.34)\end{array}$ \\
\hline \multicolumn{14}{|l|}{ Education } \\
\hline$\leq$ Primary & $6.3 \%$ & $\begin{array}{c}1.75 \\
(1.06,2.90)^{*}\end{array}$ & $\begin{array}{c}1.77 \\
(1.04,3.03)^{*}\end{array}$ & $\begin{array}{c}2.59 \\
(1.13,5.93)^{*}\end{array}$ & $\begin{array}{c}2.61 \\
(1.07,6.40)^{*}\end{array}$ & $\begin{array}{c}1.05 \\
(0.84,1.32)\end{array}$ & $\begin{array}{c}1.05 \\
(0.84,1.32)\end{array}$ & $\begin{array}{c}0.26 \\
(0.04,1.78)\end{array}$ & $\begin{array}{c}0.29 \\
(0.05,1.89)\end{array}$ & $\begin{array}{c}0.65 \\
(0.36,1.20)\end{array}$ & $\begin{array}{c}0.71 \\
(0.40,1.24)\end{array}$ & $\begin{array}{c}0.55 \\
(0.08,3.69)\end{array}$ & $\begin{array}{c}0.44 \\
(0.08,2.54)\end{array}$ \\
\hline Secondary & $57.1 \%$ & $\begin{array}{c}1.09 \\
(0.76,1.56)\end{array}$ & $\begin{array}{c}1.07 \\
(0.73,1.56)\end{array}$ & $\begin{array}{c}1.79 \\
(1.00,3.21)\end{array}$ & $\begin{array}{c}1.50 \\
(0.81,2.78)\end{array}$ & $\begin{array}{c}1.03 \\
(0.91,1.16)\end{array}$ & $\begin{array}{c}1.00 \\
(0.88,1.14)\end{array}$ & $\begin{array}{c}0.56 \\
(0.32,0.98)^{*}\end{array}$ & $\begin{array}{c}0.61 \\
(0.35,1.06)\end{array}$ & $\begin{array}{c}0.66 \\
(0.51,0.85)^{*}\end{array}$ & $\begin{array}{c}0.70 \\
(0.54,0.90) *\end{array}$ & $\begin{array}{c}1.16 \\
(0.64,2.10)\end{array}$ & $\begin{array}{c}1.20 \\
(0.61,2.38)\end{array}$ \\
\hline More than secondary & $36.5 \%$ & Reference & N/A & N/A & N/A & N/A & N/A & N/A & N/A & N/A & N/A & N/A & N/A \\
\hline \multicolumn{14}{|l|}{ Origin } \\
\hline From Lima & $46.5 \%$ & $\begin{array}{c}0.86 \\
(0.62,1.19)\end{array}$ & $\begin{array}{c}0.92 \\
(0.65,1.29)\end{array}$ & $\begin{array}{c}1.34 \\
(0.83,2.15)\end{array}$ & $\begin{array}{c}1.13 \\
(0.70,1.84)\end{array}$ & $\begin{array}{c}1.00 \\
(0.89,1.13)\end{array}$ & $\begin{array}{c}0.98 \\
(0.87,1.10)\end{array}$ & $\begin{array}{c}0.67 \\
(0.37,1.20)\end{array}$ & $\begin{array}{c}0.64 \\
(0.36,1.15)\end{array}$ & $\begin{array}{c}0.79 \\
(0.61,1.03)\end{array}$ & $\begin{array}{c}0.80 \\
(0.62,1.04)\end{array}$ & $\begin{array}{c}0.99 \\
(0.55,1.78)\end{array}$ & $\begin{array}{c}0.68 \\
(0.36,1.28)\end{array}$ \\
\hline From outside Lima & $53.5 \%$ & Reference & N/A & N/A & N/A & N/A & N/A & N/A & N/A & $\mathrm{N} / \mathrm{A}$ & $\mathrm{N} / \mathrm{A}$ & N/A & N/A \\
\hline \multicolumn{14}{|l|}{ Employment } \\
\hline Employed & $79.1 \%$ & $\begin{array}{c}1.22 \\
(0.78,1.91)\end{array}$ & $\begin{array}{c}1.14 \\
(0.69,1.87)\end{array}$ & $\begin{array}{c}0.37 \\
(0.23,0.58)^{*}\end{array}$ & $\begin{array}{c}0.48 \\
(0.27,0.85)^{*}\end{array}$ & $\begin{array}{c}0.86 \\
(0.77,0.96)^{*}\end{array}$ & $\begin{array}{c}0.88 \\
(0.76,1.02)\end{array}$ & $\begin{array}{c}1.04 \\
(0.51,2.12)\end{array}$ & $\begin{array}{c}1.01 \\
(0.47,2.18)\end{array}$ & $\begin{array}{c}1.06 \\
(0.76,1.47)\end{array}$ & $\begin{array}{c}0.95 \\
(0.66,1.37)\end{array}$ & $\begin{array}{c}0.68 \\
(0.36,1.28)\end{array}$ & $\begin{array}{c}0.52 \\
(0.21,1.27)\end{array}$ \\
\hline Unemployed & $20.9 \%$ & Reference & N/A & N/A & N/A & N/A & N/A & N/A & N/A & N/A & N/A & N/A & N/A \\
\hline Sex Work & $48.2 \%$ & $\begin{array}{l}1.13 \\
(0.81,1.56)\end{array}$ & $\begin{array}{c}0.90 \\
0.61,1.33)\end{array}$ & $\begin{array}{c}0.48 \\
(0.29,0.81)^{*}\end{array}$ & $\begin{array}{c}0.75 \\
(0.39,1.43)\end{array}$ & $\begin{array}{c}0.92 \\
(0.82,1.04)\end{array}$ & $\begin{array}{c}1.00 \\
(0.87,1.15)\end{array}$ & $\begin{array}{c}0.99 \\
(0.57,1.73)\end{array}$ & $\begin{array}{c}0.74 \\
(0.38,1.44)\end{array}$ & $\begin{array}{c}1.06 \\
(0.82,1.36)\end{array}$ & $\begin{array}{c}0.98 \\
(0.73,1.31)\end{array}$ & $\begin{array}{c}1.00 \\
(0.56,1.79)\end{array}$ & $\begin{array}{c}1.31 \\
(0.55,3.09)\end{array}$ \\
\hline No sex work & $51.8 \%$ & Reference & N/A & N/A & N/A & N/A & N/A & N/A & N/A & N/A & N/A & N/A & N/A \\
\hline \multicolumn{14}{|c|}{ Gender identity } \\
\hline Trans or transgender & $58.5 \%$ & Reference & $\mathrm{N} / \mathrm{A}$ & N/A & N/A & N/A & N/A & N/A & N/A & N/A & N/A & $\mathrm{N} / \mathrm{A}$ & N/A \\
\hline Woman & $15.3 \%$ & $\begin{array}{c}1.06 \\
(0.70,1.62)\end{array}$ & $\begin{array}{c}1.09 \\
(0.72,1.66)\end{array}$ & $\begin{array}{c}0.69 \\
(0.31,1.55)\end{array}$ & $\begin{array}{c}0.77 \\
(0.35,1.69)\end{array}$ & $\begin{array}{c}0.93 \\
(0.77,1.12)\end{array}$ & $\begin{array}{c}0.93 \\
(0.77,1.12)\end{array}$ & $\begin{array}{c}1.64 \\
(0.85,3.17)\end{array}$ & $\begin{array}{c}1.69 \\
(0.89,3.22)\end{array}$ & $\begin{array}{c}1.55 \\
(1.19,2.02)^{*}\end{array}$ & $\begin{array}{c}1.49 \\
(1.16,1.91)^{*}\end{array}$ & $\begin{array}{c}1.94 \\
(01.00,3.76)\end{array}$ & $\begin{array}{c}2.36 \\
(1.15,4.80)^{*}\end{array}$ \\
\hline Trans-sexual & $8.3 \%$ & $\begin{array}{c}0.72 \\
(0.35,1.47)\end{array}$ & $\begin{array}{c}0.75 \\
(0.36,1.57)\end{array}$ & $\begin{array}{c}1.11 \\
(0.48,2.55)\end{array}$ & $\begin{array}{c}0.94 \\
(0.44,2.02)\end{array}$ & $\begin{array}{c}1.07 \\
(0.90,1.28)\end{array}$ & $\begin{array}{c}1.05 \\
(0.88,1.24)\end{array}$ & $\begin{array}{c}1.57 \\
(0.66,3.71)\end{array}$ & $\begin{array}{c}1.66 \\
(0.72,3.80)\end{array}$ & $\begin{array}{c}1.09 \\
(0.69,1.72)\end{array}$ & $\begin{array}{c}1.09 \\
(0.69,1.73)\end{array}$ & $\begin{array}{c}1.85 \\
(0.74,4.64)\end{array}$ & $\begin{array}{c}1.62 \\
(0.66,4.02)\end{array}$ \\
\hline Transformista & $9.0 \%$ & $\begin{array}{c}0.59 \\
(0.21,1.64)\end{array}$ & $\begin{array}{c}0.62 \\
(0.23,1.67)\end{array}$ & $\begin{array}{c}1.45 \\
(0.60,3.52)\end{array}$ & $\begin{array}{c}1.01 \\
(0.39,2.59)\end{array}$ & $\begin{array}{c}1.15 \\
(0.98,1.35)\end{array}$ & $\begin{array}{c}1.08 \\
(0.91,1.27)\end{array}$ & $\begin{array}{c}1.03 \\
(0.27,3.92)\end{array}$ & $\begin{array}{c}1.09 \\
(0.33,3.60)\end{array}$ & $\begin{array}{c}0.98 \\
(0.52,1.83)\end{array}$ & $\begin{array}{c}0.98 \\
(0.49,1.94)\end{array}$ & $\begin{array}{c}0.00 \\
(0.00,0.00)\end{array}$ & $\begin{array}{c}0.00 \\
(0.00,0.00)\end{array}$ \\
\hline Travesti & $7.0 \%$ & $\begin{array}{c}0.81 \\
(0.38,1.73)\end{array}$ & $\begin{array}{c}0.76 \\
(0.38,1.53)\end{array}$ & $\begin{array}{c}1.80 \\
(0.88,3.66)\end{array}$ & $\begin{array}{c}1.21 \\
(0.60,2.44)\end{array}$ & $\begin{array}{c}1.02 \\
(0.81,1.28)\end{array}$ & $\begin{array}{c}0.99 \\
(0.78,1.22)\end{array}$ & $\begin{array}{c}0.00^{*} \\
(0.00,0.00)\end{array}$ & $\begin{array}{c}0.00 \\
(0.00,0.00)^{*}\end{array}$ & $\begin{array}{c}0.40 \\
(0.14,1.14)\end{array}$ & $\begin{array}{c}0.50 \\
(0.17,1.44)\end{array}$ & $\begin{array}{c}0.67 \\
(0.10,4.46)\end{array}$ & $\begin{array}{c}0.51 \\
(0.09,2.90)\end{array}$ \\
\hline Other & $2.0 \%$ & $\begin{array}{c}1.37 \\
(0.50,3.74)\end{array}$ & $\begin{array}{c}1.15 \\
(0.45,2.90)\end{array}$ & $\begin{array}{c}0.00 \\
(0.00,0.00)^{*}\end{array}$ & $\begin{array}{c}0.00 \\
(0.00,0.00)^{*}\end{array}$ & $\begin{array}{c}0.62 \\
(0.23,1.65)\end{array}$ & $\begin{array}{c}0.62 \\
(0.24,1.61)\end{array}$ & $\begin{array}{c}1.80 \\
(0.32,10.27)\end{array}$ & $\begin{array}{c}1.49 \\
(0.35,6.37)\end{array}$ & $\begin{array}{c}1.14 \\
(0.42,3.08)\end{array}$ & $\begin{array}{c}1.00 \\
(0.38,2.70)\end{array}$ & $\begin{array}{c}6.00 \\
(3.93,9.16)^{*}\end{array}$ & $\begin{array}{c}5.64 \\
(2.75,11.58) *\end{array}$ \\
\hline
\end{tabular}


medRxiv preprint doi: https://doi.org/10.1101/2022.02.01.22270281; this version posted February 2, 2022. The copyright holder for this preprint (which was not certified by peer review) is the author/funder, who has granted medRxiv a license to display the preprint in perpetuity.

All rights reserved. No reuse allowed without permission.

\section{References}

1. Transgender Stigma and Health: A Critical Review of Stigma Determinants, Mechanisms, and Interventions. Accessed October 27, 2021. https://www.ncbi.nlm.nih.gov/pmc/articles/PMC4689648/

2. Care of the Transgender Patient | Annals of Internal Medicine. Accessed October 27, 2021. https://www.acpjournals.org/doi/10.7326/AITC201907020?url_ver=Z39.88-

2003\&rfr_id=ori:rid:crossref.org\&rfr_dat $=$ cr_pub\%20\%200pubmed

3. Wierckx K, Elaut E, Declercq E, et al. Prevalence of cardiovascular disease and cancer during cross-sex hormone therapy in a large cohort of trans persons: a case-control study. Eur J Endocrinol. 2013;169(4):471-478. doi:10.1530/EJE-13-0493

4. Reisner SL, Poteat T, Keatley J, et al. Global health burden and needs of transgender populations: a review. The Lancet. 2016;388(10042):412-436. doi:10.1016/S0140-6736(16)00684-X

5. TMM Update Trans Day of Remembrance 2018. TvT. Published November 12, 2018. Accessed October 27, 2021. https://transrespect.org/en/tmm-update-tdor-2018/

6. Perez-Brumer A, Silva-Santisteban A. COVID-19 Policies can Perpetuate Violence Against Transgender Communities: Insights from Peru. AIDS Behav. 2020;24(9):2477-2479. doi:10.1007/s 10461020-02889-Z

7. The injustices faced by transgender women in Peru| UNAIDS. Accessed July 6, 2021. https://www.unaids.org/en/resources/presscentre/featurestories/2018/april/injustices-faced-bytransgender-women-in-peru

8. Malta M, Cardoso R, Montenegro L, et al. Sexual and gender minorities rights in Latin America and the Caribbean: a multi-country evaluation. BMC Int Health Hum Rights. 2019;19(1):31.

doi:10.1186/s12914-019-0217-3

9. HIV/AIDS, human rights, and transgender people in Latin America - The Lancet Public Health. Accessed October 27, 2021. https://www.thelancet.com/journals/lanpub/article/PIIS2468-2667(19)300829/fulltext

10. Violence against Lesbian, Gay, Bisexual, Trans and Intersex Persons in the Americas. InterAmerican Commission on Human Rights; 2015. Accessed October 27, 2021. http://www.oas.org/en/iachr/reports/pdfs/violencelgbtipersons.pdf

11. TMM Resources. TvT. Accessed July 6, 2021. https://transrespect.org/en/trans-murdermonitoring/tmm-resources/

12. Clark JL, Perez-Brumer AG, Reisner SL, et al. Social Network Organization, Structure, and Patterns of Influence Within a Community of Transgender Women in Lima, Peru: Implications for Biomedical HIV Prevention. AIDS Behav. 2020;24(1):233-245. doi:10.1007/s10461-019-02506-8

13. Silva-Santisteban A, Raymond HF, Salazar X, et al. Understanding the HIV/AIDS epidemic in transgender women of Lima, Peru: results from a sero-epidemiologic study using respondent driven sampling. AIDS Behav. 2012;16(4):872-881. doi:10.1007/s10461-011-0053-5

14. The Night is Another Country: Impunity and Violence against Transgender Women Human Rights Defenders in Latin America | CLAC.CAB. Accessed October 27, 2021. https://clac.cab/portfolioitem/night-another-country-impunity-and-violence-against-transgender-women-human-rights 
medRxiv preprint doi: https://doi.org/10.1101/2022.02.01.22270281; this version posted February 2, 2022. The copyright holder for this preprint (which was not certified by peer review) is the author/funder, who has granted medRxiv a license to display the preprint in perpetuity.

All rights reserved. No reuse allowed without permission.

15. Bayer AM, Mallma P, Cárcamo CP, et al. ¿Te recurseas? Mapping, enumerating and describing male and transwomen sex workers in venue-based and virtual spaces in Lima, Peru. AIDS Educ Prev Off Publ Int Soc AIDS Educ. 2019;31(6):567-583. doi:10.1521/aeap.2019.31.6.567

16. Salazar X, Núnez-Curto A, Villayzán Aguilar J, Lusquiños M, Motta Ochoa A, Cáceres CF. Confluent paths: Research and community participation to protect the right to health among transgender women in Peru. Glob Public Health. 2019;14(6-7):954-962. doi:10.1080/17441692.2019.1599982

17. Blueprint for the Provision of Comprehensive Care for Trans Persons and Their Communities in the Caribbean and Other Anglophone Countries. Pan American Health Organization [PAHO], John Snow, Inc., World Professional Association for Transgender Health; 2014. Accessed July 16, 2021. https://www.paho.org/en/file/39610/download?token=S56Unhmm

18. Ortiz-Martínez Y, Ríos-González CM. Need for more research on and health interventions for transgender people. Sex Health. 2017;14(2):196-197. doi:10.1071/SH16148

19. Pollock L, Silva-Santisteban A, Sevelius J, Salazar X. "You should build yourself up as a whole product": Transgender female identity in Lima, Peru. Glob Public Health. 2016;11(7-8):981-993. doi:10.1080/17441692.2016.1167932

20. Transgender Population Size in the United States: a Meta-Regression of Population-Based Probability Samples | AJPH | Vol. 107 Issue 2. Accessed October 27, 2021. https://ajph.aphapublications.org/doi/10.2105/AJPH.2016.303578

21. The Gender Identity in U.S. Surveillance (GenIUSS) Group. Best Practices for Asking Questions to Identify Transgender and Other Gender Minority Respondents on Population-Based Surveys. The Williams Institute; 2014. Accessed July 16, 2021. https://williamsinstitute.law.ucla.edu/wpcontent/uploads/Survey-Measures-Trans-GenIUSS-Sep-2014.pdf

22. M Pun. Situación de la epidemia de VIH en Perú. Red Nacional de Epidemiologia; 2015. Accessed July 16, 2021.

https://web.kamihq.com/web/viewer.html?source=extension_pdfhandler\&file $=$ https $\% 3 \mathrm{~A} \% 2 \mathrm{~F} \% 2 \mathrm{Fwww}$. minsa.gob.pe\%2Fportada\%2FEspeciales\%2F2015\%2Fvih\%2Fmatcom\%2FSituacion-EpidemiologicaVIH-2015.pdf

23. The World Bank. Prevalence of HIV, total (\% of population ages 15-49) - Peru | Data. Accessed October 27, 2021.

https://data.worldbank.org/indicator/SH.DYN.AIDS.ZS?end=2020\&locations=PE\&start=1990\&view=ch art

24. Dirección General de Epidemiología- IMPACTA. Vigilancia Epidemiológica en VIH en Población HSH 2011. Ministerio de Salud; 2012. Accessed July 16, 2021. https://scholar.google.com/scholar?q=Direcci\%C3\%B3n+General+de+Epidemiolog\%C3\%ADa+ IMPACTA+Vigilancia+Epidemiol\%C3\%B3gica+en+VIH+en+Poblaci\%C3\%B3n+HSH+2011+2012+P eru+Ministerio + de + Salud +

25. Dirección General de Intervenciones Estratégicas en Salud Pública del Ministerio de Salud. Resolución Ministerial. Vol 980-2016-MINSA.; 2016. https://cdn.www.gob.pe/uploads/document/file/192718/191440_RM_N_980-2016-MINSA.pdf2018090420266-unuk00.pdf 
medRxiv preprint doi: https://doi.org/10.1101/2022.02.01.22270281; this version posted February 2, 2022. The copyright holder for this preprint (which was not certified by peer review) is the author/funder, who has granted medRxiv a license to display the preprint in perpetuity.

All rights reserved. No reuse allowed without permission.

26. Reisner SL, Perez-Brumer AG, McLean SA, et al. Perceived Barriers and Facilitators to Integrating HIV Prevention and Treatment with Cross-Sex Hormone Therapy for Transgender Women in Lima, Peru. AIDS Behav. 2017;21(12):3299-3311. doi:10.1007/s10461-017-1768-8

27. Longino A, Montano MA, Sanchez H, et al. Increasing PrEP Uptake and Adherence among MSM and TW Sex Workers in Lima, Perú: What and Whom Do Different Patients Trust? AIDS Care. 2020;32(2):255-260. doi:10.1080/09540121.2019.1634787

28. Fundação Osvaldo Cruz, Ministry of Health of Brazil, University Caetano Heredia, Condesa Clinic, UNITAID. ImPrEP Project. Accessed October 27, 2021. http://imprep.org/peru/o-projeto-imprep/

29. Prep Vih. Mercado Libre Peru. Accessed January 28, 2022.

https://listado.mercadolibre.com.pe/prep-vih

30. AVAC. A Snapshot of PrEP scale-up, registration and resources for Peru. PrEPWatch. Published October 15, 2021. Accessed October 27, 2021. https://www.prepwatch.org/country/peru/

31. Comercio E. La lucha de las mujeres trans en tiempos de pandemia |El Comercio. El Comercio.pe. Accessed November 19, 2021. https://especiales.elcomercio.pe/?q=especiales/mujerestrans-en-tiempos-de-pandemia-ecpm/index.html

32. Chow JY, Konda KA, Borquez A, et al. Peru's HIV care continuum among men who have sex with men and transgender women: opportunities to optimize treatment and prevention. Int J STD AIDS. 2016;27(12):1039-1048. doi:10.1177/0956462416645727

33. Peru 2016 Human Rights Report. United States Department of State, Bureau of Democracy, Human Rights and Labor; 2016:36. Accessed July 16, 2021. https://www.state.gov/wpcontent/uploads/2019/01/Peru-1.pdf

34. Perez-Brumer AG, Reisner SL, McLean SA, et al. Leveraging social capital: multilevel stigma, associated HIV vulnerabilities, and social resilience strategies among transgender women in Lima, Peru. $J$ Int AIDS Soc. 2017;20(1):21462. doi:10.7448/IAS.20.1.21462

35. Galea JT, Kinsler JJ, Salazar X, et al. Acceptability of pre-exposure prophylaxis as an HIV prevention strategy: barriers and facilitators to pre-exposure prophylaxis uptake among at-risk Peruvian populations. Int J STD AIDS. 2011;22(5):256-262. doi:10.1258/ijsa.2009.009255

36. Cindy Carolina Martinez Ramirez Bach. Centro Comunitario y Albergue para Personas Transgénero en el Distrito de la Victoria. Published online October 2020. Accessed October 27, 2021. https://repositorio.urp.edu.pe/bitstream/handle/URP/3398/T030_46418643_T\%20\%20\%20CINDY\%20C AROLINA\%20MARTINEZ\%20RAMIREZ.pdf?sequence=1\&isAllowed=y

37. Yerson Collave García. La nueva opción para prevenir el VIH que se probó en Perú (y que demostró ser eficaz). El Comercio Perú. https://elcomercio.pe/tecnologia/ciencias/vih-sida-cabotegravirla-nueva-opcion-para-prevenir-el-vih-que-se-probo-en-peru-y-que-demostro-ser-eficaz-noticia/. Published September 10, 2021. Accessed January 28, 2022.

38. Long-Acting Injectable Form of HIV Prevention Outperforms Daily Pill in NIH Study. NIH National Institute of Allergy and Infectious Diseases. Published July 7, 2020. Accessed January 28, 2022. https://www.niaid.nih.gov/news-events/long-acting-injectable-form-hiv-prevention-outperforms-dailypill-nih-study 
medRxiv preprint doi: https://doi.org/10.1101/2022.02.01.22270281; this version posted February 2, 2022. The copyright holder for this preprint (which was not certified by peer review) is the author/funder, who has granted medRxiv a license to display the preprint in perpetuity.

All rights reserved. No reuse allowed without permission.

39. FDA Approves First Injectable Treatment for HIV Pre-Exposure Prevention. FDA. Published December 20, 2021. Accessed January 28, 2022. https://www.fda.gov/news-events/pressannouncements/fda-approves-first-injectable-treatment-hiv-pre-exposure-prevention

40. World Health Organization. Global Tuberculosis Report 2020. World Health Organization; 2020.

41. Yacila RC. Ni empleadas ni ciudadanas: no hay tregua para las mujeres trans. Ojo Público. https://ojo-publico.com/2979/no-hay-tregua-para-las-mujeres-trans-en-peru. Published August 29, 2021. Accessed January 28, 2022.

42. Willie B, Hakim AJ, Badman SG, et al. High prevalence of pulmonary tuberculosis among female sex workers, men who have sex with men, and transgender women in Papua New Guinea. Trop Med Health. 2021;49(1):4. doi:10.1186/s41182-020-00293-w

43. Age Groups - MeSH - NCBI. Accessed October 27, 2021.

https://www.ncbi.nlm.nih.gov/mesh/68009273 